\title{
IDENTIFICATION OF THEORETICAL PARAMETERS USED TO FORECAST UNDERGROUND MINING IMPACTS TO IMPLEMENT LONG-TERMS FORECASTS OF UNDERGROUND MINING IMPACTS - CASE STUDY
}

\author{
${ }^{1}$ Silesian University of Technology, Faculty of Mining, Safety Engineering and Industrial Automation, Gliwice, Poland
}

Keywords: subsidence, deformation prediction, Knothe's prediction model parameters, coefficient of roof control

\begin{abstract}
The paper is a case study of ground surface subsidence induced by a long-term mining of hard coal. Knothe prediction model is commonly used in Poland as a technique for prediction of the subsidence-related deformation of ground surface. The presented issue is related to assumptions about the value of the theory parameters in long-term forecasts on the impact of mining on the surface, which are included in the mine development plan. Incorrectly selected values can significantly influence the quality of deformation forecasts.

The calculations presented in the article were made for the area where the exploitation of six coal seams lasted more than thirty years. At the same time, deformations of the surface were observed by means of geodetic measurements. Based on the subsidence curves of the observation line points over time, three periods of rock movement decrease were determined. The range of mining operations was determined for the periods of decreased rock movements. The parameters of Knothe's model were identified on the basis of geodetic measurements for extracted coal seams. Parametric calculations were made for the increasing range of mining operations and for the ranges of operation between subsequent decreases in the movements of the rock mass. Identification of the parameters of the theory thus made it possible to trace changes in the parameter values for different mining ranges. Significant changes were noted for the parameter describing the dispersion of influence $(\tan \beta)$, while changes in the coefficient of roof control are not significant and their value becomes stable after some time. As the extent of the mining exploitation was increasing, its influence on both parameters (tangent of angle of major influence $-\tan \beta$ and coefficient of roof control ' $a$ ') were evaluated. The changes of $\tan \beta$ values were found to be significant whereas the changes of the ' $a$ ' coefficient value are negligible and its value seems to be constant after the initial stage of mining.
\end{abstract}

\section{IDENTYFIKACJA PARAMETRÓW TEORII PROGNOZOWANIA WPLYWÓW DO SPORZĄDZANIA WIELOLETNICH PROGNOZ WPLYWÓW EKSPLOATACJI GÓRNICZEJ - STUDIUM PRZYPADKU}

Słowa kluczowe: osiadanie, prognozowanie deformacji, parametry teorii prognozowania Knothego, współczynnik kierowania stropem

\footnotetext{
Abstrakt

W artykule przedstawiono przypadek identyfikacji parametrów teorii prognozowania wpływów S. Knothego dla wieloletniej podziemnej eksploatacji górniczej. Przedstawione zagadnienie jest związane z założeniami co do wartości parametrów teorii w długoterminowych prognozach wpływu eksploatacji złoża na powierzchnię, zawartych w projekcie zagospodarowania złoża. Nieprawidłowo dobrane wartości mogą znacząco wpływać na jakość sporządzanych prognoz deformacji.
} 
Prezentowane w artykule obliczenia wykonano dla rejonu, w którym prowadzono eksploatację sześciu pokładów węgla $\mathrm{w}$ okresie ponad trzydziestu lat, natomiast na powierzchni obserwowano powstające deformacje z wykorzystaniem pomiarów geodezyjnych. Na podstawie krzywych osiadań punktów linii obserwacyjnej w czasie określono trzy okresy zatrzymania ruchów górotworu. Dla okresów zatrzymania ruchów górotworu określono zakres dotychczasowej eksploatacji górniczej. Na podstawie pomiarów geodezyjnych oraz zakresu wybranych pokładów przeprowadzono identyfikację parametrów teorii S. Knothego. Obliczenia parametrów wykonano dla zwiększającego się zakresu eksploatacji górniczej oraz dla zakresów eksploatacji pomiędzy kolejnymi zatrzymaniami ruchów górotworu. Przeprowadzona w ten sposób identyfikacja parametrów teorii stworzyła możliwość prześledzenia zmian wartości parametrów dla różnych zakresów eksploatacji górniczej. Stwierdzono istotne zmiany w przypadku parametru opisującego rozproszenie wpływów $(\operatorname{tg} \beta)$, natomiast zmiany wartości współczynnika eksploatacji nie są znaczne, a jego wartość po pewnym czasie ustala się na stałym poziomie.

\section{INTRODUCTION}

The mine development plan (PZZ in Polish) is one of the basic documents attached to the application for a concession. PZZ determines changes resulting from operation over the entire concession period, which includes calculations of predicted land deformation within long periods (Rozporządzenie... 2012).

Rational mineral economy imposes minimization of environmental damage caused by mining. Exploitation of underground mines results in a number of transformations in the environment, which primarily include deformation of the terrain observed as subsidence. Knothe's model is the most common calculation method of forecasting surface changes (Knothe 1953, 1984), and then the deformation indicators are calculated which are necessary to assess the impact of surface-to-surface operations. The quality of the predictions is largely dependent on the parameters of the theory. Values of parameters describe geological and mining conditions of extraction. Previous experience in the field of forecasting of the impact of exploitation on the surface makes it possible to conclude that the values of the parameters should be taken on the basis of their identification based on the survey results, which can significantly increase the reliability of the conducted studies.

When determining the value of parameters based on geodetic survey results, several conditions should be met, without which the process of identifying parameters would not be complete. These include, among others, the following: the subsidence trough profile should represent the final state of deformation, not affected by indirect influences (rock dehydration, goafs activation), while the geodetic measurements should represent the full deformation of the surface. Previously, it was thought that the identification of the parameters should be related to the state of deformation resulting from the extraction of a single longwall. In the case of exploitation at great depths, the interaction of a single field (longwall panel) with the surface can cause slight decrease of values and only the extraction of subsequent fields makes it possible to identify the parameters of the theory. It should also be noted that the intensity of the extraction, which results in the deformation caused by the extraction of consecutive longwall panels at different times overlaps and the final state of deformation may be caused by the influence of several fields in various coal seams.

All of the aforementioned aspects indicate that the measured profile of the subsidence trough can be used for the identification of parameters, which covers not a single field or several longwall panels in just a few coal seams but the whole range of operations. That approach to the problem can be considered controversial, but it is important to note that mean values of the theoretical parameters for all the considered operating fields are used to calculate the long-term exploitation effects.

The purpose of this article was to provide an example of the identification of the influence forecasting theory parameters on the basis of the changing asymptotic state of deformation due to the extraction in subsequent coal seams conducted over a long period of time. Issues related to the identification of parameters of Knothe's model were previously discussed in the literature of the subject (Kowalski 1984, Strzałkowski 1989, Tyrała 1993, Zych 2000, Białek and Mielimąka 2001, 2006, Ścigała 2006, Chudek M. et al. 2007, Kowalski 2015, Mielimąka 2019, Kruczkowski 2019).

It should also be mentioned that many studies related to the issue presented in this paper have been written so far. The studies can be divided into the following groups:

- articles containing modelling of the deformation process as a result of mining exploitation (Singh and Yadav 1995, Tajduś 2007, Wesołowski 2013, Ghabraie et al. 2017a), 
- statistical analyses and uncertainty of Knothe's model parameters (Hejmanowski and Malinowska 2009, Hejmanowski and Malinowska 2016, Gruszczyński et al. 2018),

- analysis of the results of measurements (Singh and Singh 1998, Doležalová et al. 2010, Ghabraie et al. 2017b).

\section{RANGE OF UNDERGROUND MINING AND GEODETIC OBSERVATIONS}

Research was conducted for geodetic survey and mining operations in the one of coal mines of the Upper Silesian Coal Basin.

The rock mass consists of: Quaternary formations (sands and gravels), Neogene formations (grey loams), Upper Carboniferous structures (Orzesze layers with dominance of claystones and mudstones over finegrained sandstones). Thickness of overburden strata is from $270 \mathrm{~m}$ to $345 \mathrm{~m}$.
In this area, underground mining has been conducted for more than thirty years. Up to now, six coal seams have been extracted with caving at a depth between $440 \mathrm{~m}$ to $970 \mathrm{~m}$. The basic data on the full range of mining operations in the analyzed area are presented in Table 1.

Tab. 1. Characteristics of excavated coal seams

Tab. 1. Charakterystyka dotychczasowej eksploatacji górniczej

\begin{tabular}{|c|c|c|c|}
\hline $\begin{array}{c}\text { Coal } \\
\text { Seam }\end{array}$ & $\begin{array}{c}\text { Coal seam } \\
\text { thickness } \\
\mathbf{g} \text { [m] }\end{array}$ & $\begin{array}{c}\text { Mean depth } \\
\text { of extraction } \\
\mathbf{H} \text { [m] }\end{array}$ & $\begin{array}{c}\text { Extraction } \\
\text { time frame } \\
\text { [years] }\end{array}$ \\
\hline 1 & $1.30-1.55$ & $440-530$ & $8-14$ \\
\hline 2 & $1.30-1.90$ & $570-780$ & $1-8$ \\
\hline 3 & $1.20-1.35$ & $600-710$ & $8-16$ \\
\hline 4 & $1.95-2.10$ & $760-910$ & $21-27$ \\
\hline 5 & 2.0 & $830-960$ & $24-31$ \\
\hline 6 & 2.50 & $850-950$ & 31 \\
\hline
\end{tabular}

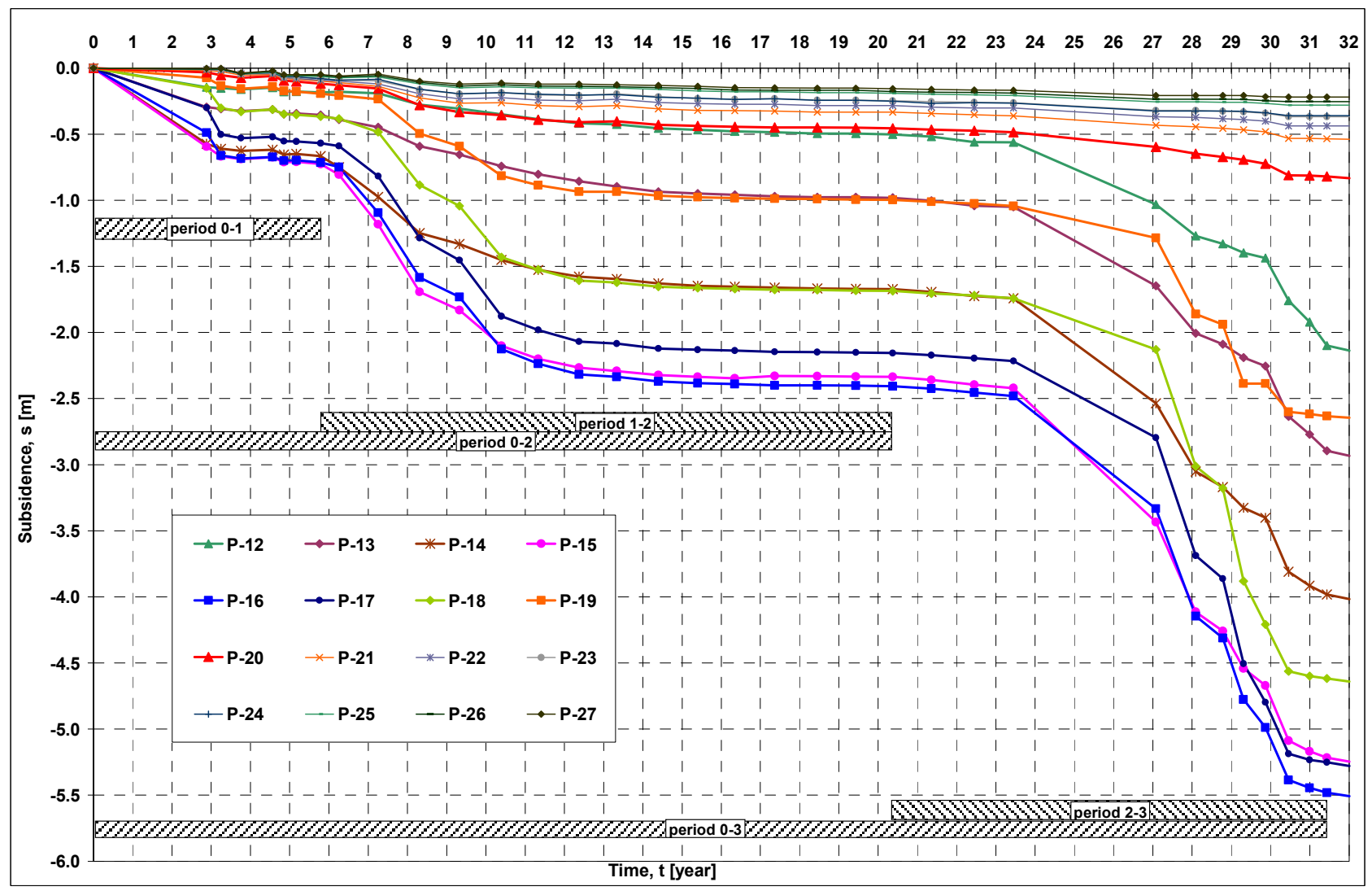

Fig. 1. Time-subsidence curves of observation points

Rys. 1. Osiadania punktów pomiarowych w czasie 
Geodetic observations on the observational line were performed for over 30 years. The location observation points is shown in Figures 2, 3, 4, 5 and 6. The first measurements were made before subsidence was revealed. Based on them, a plot of subsidence of measurement points over time was made, as shown in Figure 1. The subsidence ranges from about $-0.25 \mathrm{~m}$ in the boundary zone of the basin to about $-5.5 \mathrm{~m}$ in the maximum subsidence zone. The largest increase in subsidence occurred between the 22nd and 32nd year, and reached about $3 \mathrm{~m}$.

\section{IDENTIFICATION OF PARAMETERS OF KNOTHE MODEL}

Knothe's model (Knothe 1953, 1984) is based on the Gaussian bell-shaped influence function. Equation (1) for calculation of subsidence is as follows:

$$
s(q, t)=\iint_{P} \frac{s_{\max }}{r^{2}} e^{\frac{-\pi}{r^{2}}\left[(x-q)^{2}+(y-t)^{2}\right]} d P
$$

where:

$s_{\max }=a g-$ maximum subsidence, $[\mathrm{m}]$.

$a-$ coefficient of roof control,

$g$ - mean thickness of the exploited coal seam, [m],

$q, t$ - point coordinates, [m],

$P \quad$ - exploitation field,

$r \quad$ - the radius of major influence range, [m],

$r=H / \tan \beta, H-$ mean depth of exploitation range, [m],

$x, y$ - coordinates of elementary extraction field, [m].

For the analyses, the software developed by B. Drzęźla (Drzęźla 1989) had been used, where the minimum residual variance was adopted for the fit criterion.

Software calculates the parameters of Knothe's model: coefficient of roof control $(a), \tan \beta$ parameter and operating rim (edge effect offset $-d$, Hescock et al. 2018).

\subsection{The scope of analysis}

Three periods of decreased subsidence intensity have been identified. This division into three periods can calculate five cases of mining exploitation with their subsidence:

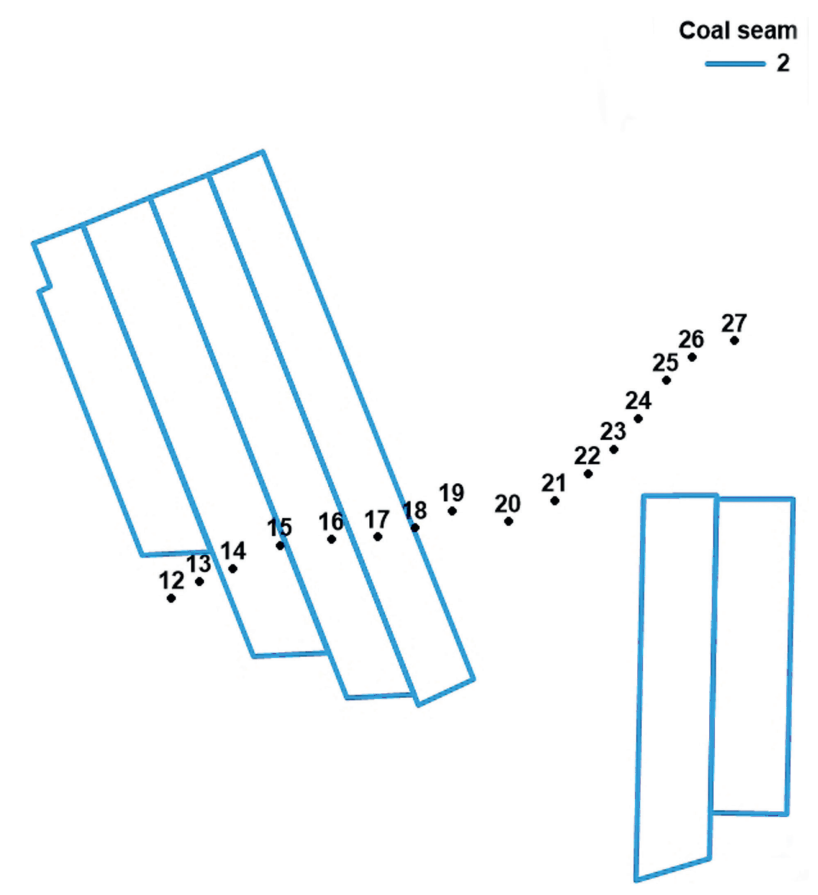

Fig. 2. Extracted longwall panels and location of observation stations - period 0-1

Rys. 2. Zakres eksploatacji górniczej w rejonie linii pomiarowej - okres 0-1

- period 0-1 (fig. 2) - exploitation of longwall panels in coal seam 2 (rock mass displacement decreased since the 6th year of exploitation),

- period 0-2 (fig. 3) - exploitation of longwall panels in coal seams 1 to 3 (rock mass displacement decreased between the 20th and 21st year of exploitation),

- period 0-3 (fig. 4) - exploitation of longwall panels in coal seams 1 to 6 (rock mass displacement decreased between the 31 st and 32 nd year of exploitation),

- period 1-2 (fig. 5) - exploitation of longwall panels in coal seams 1 to 3 (over 14 years of exploitation),

- period 2-3 (fig. 6) - exploitation of longwall panels in coal seams 4 to 6 (over 11 years of exploitation).

Based on this division of exploitation, the first three periods include aggregate influence (considered since the beginning of operation), while the last two are periodic incremental subsets (subsidence between successive decrease periods). 


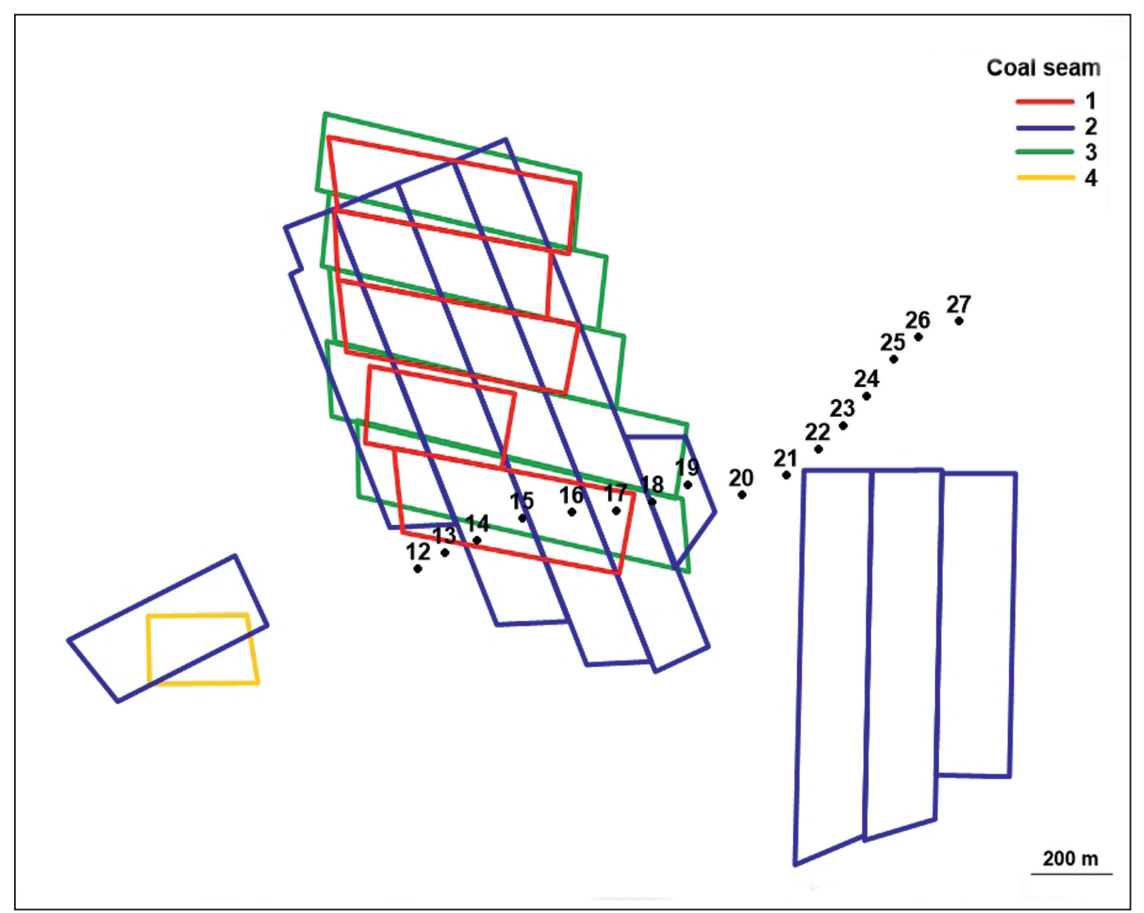

Fig. 3. Extracted longwall panels and location of observation stations - period 0-2

Rys. 3. Zakres eksploatacji górniczej w rejonie linii pomiarowej - okres 0-2

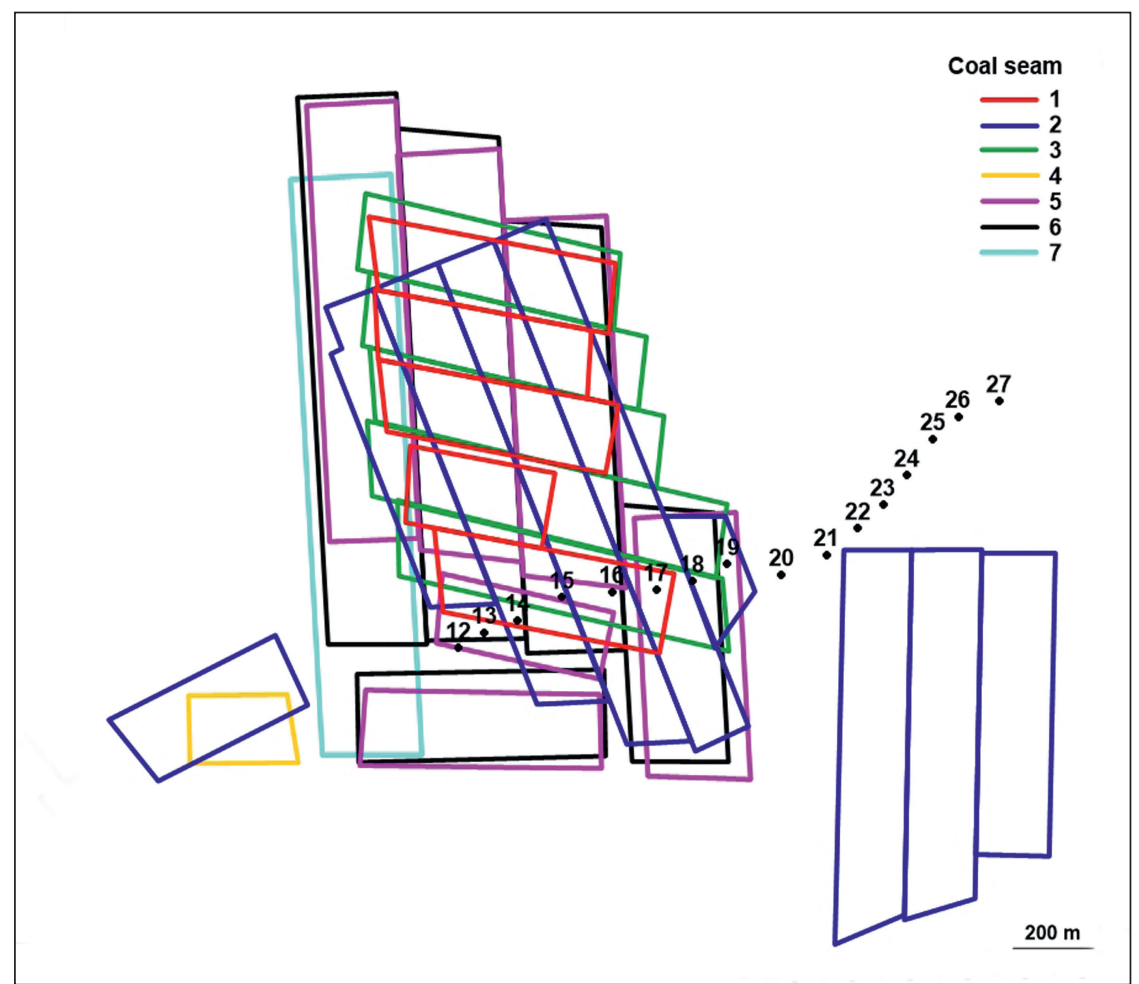

Fig. 4. Extracted longwall panels and location of observation stations - period 0-3

Rys. 4. Zakres eksploatacji górniczej w rejonie linii pomiarowej - okres 0-3 


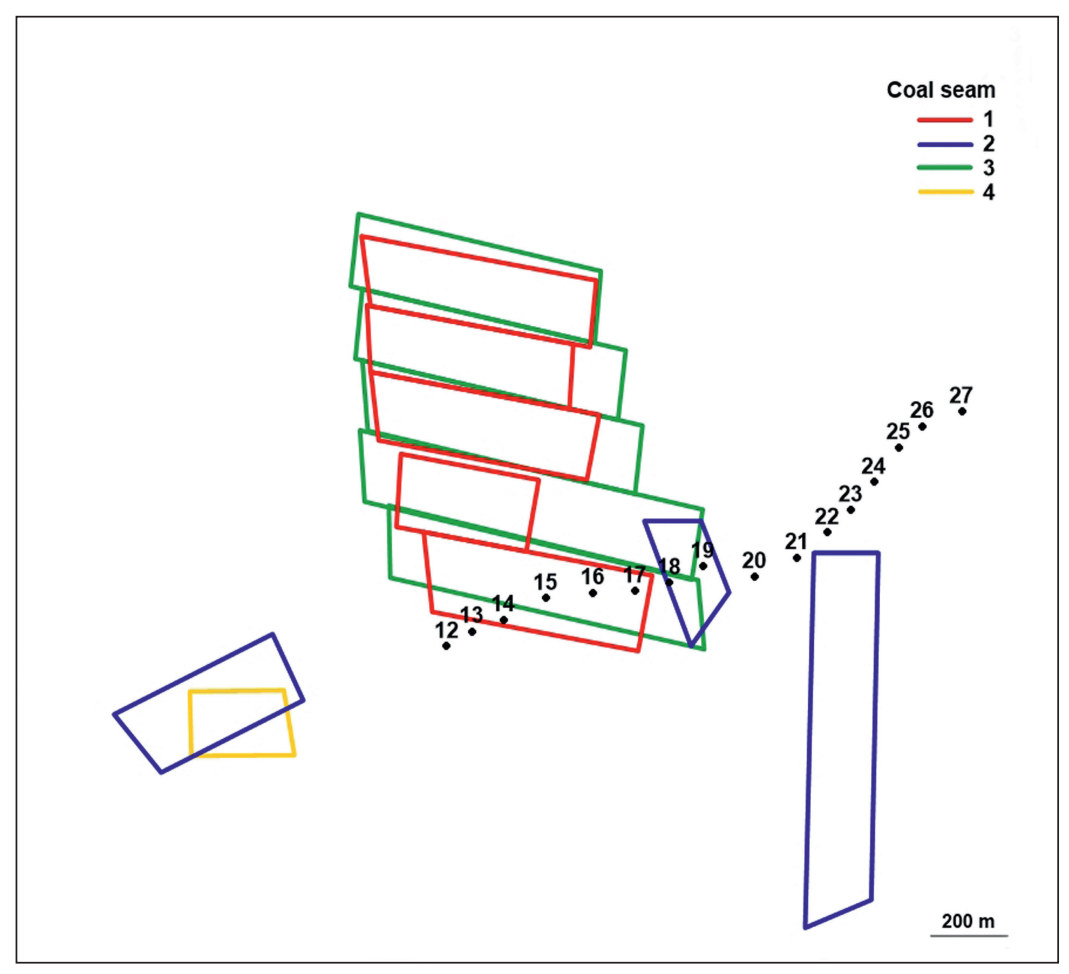

Fig. 5. Extracted longwall panels and location of observation stations - period 1-2

Rys. 5. Zakres eksploatacji górniczej w rejonie linii pomiarowej - okres 1-2

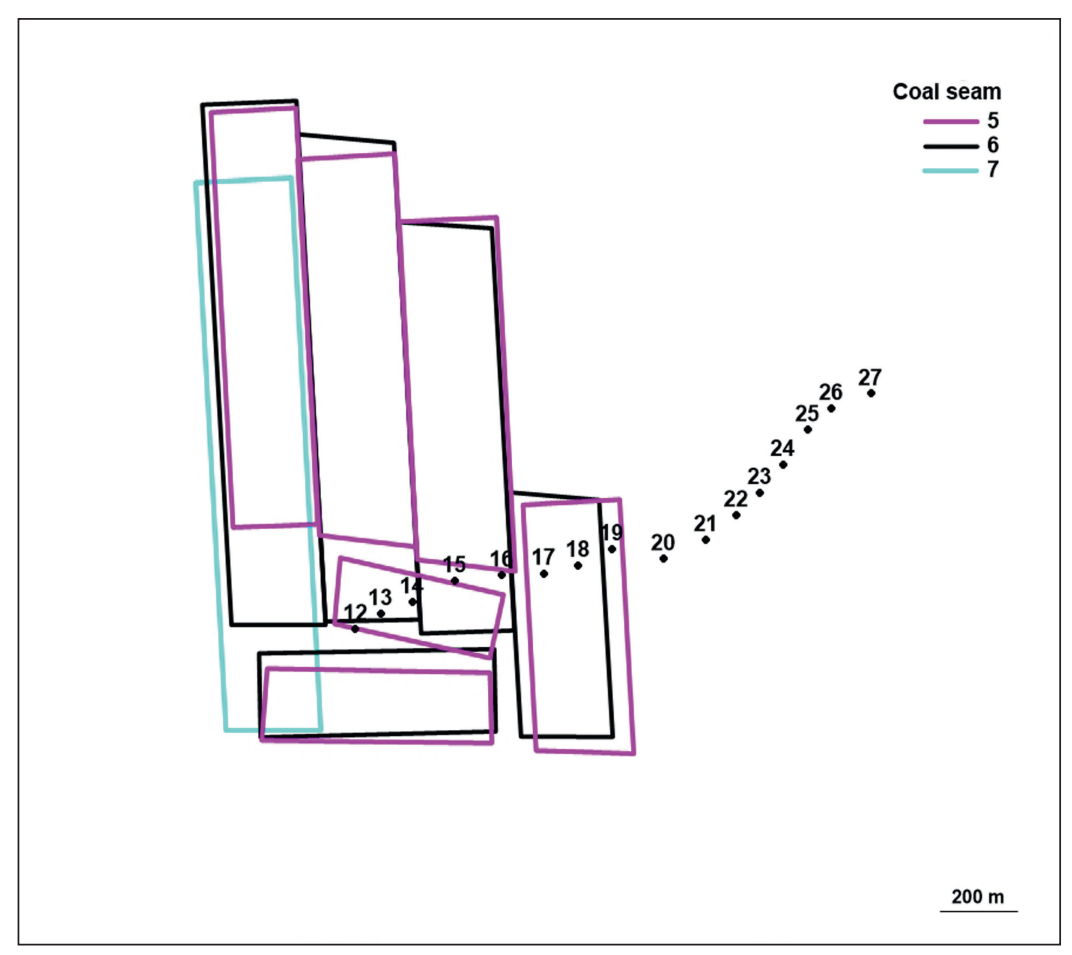

Fig. 6. Extracted longwall panels and location of observation stations - period 2-3

Rys. 6. Zakres eksploatacji górniczej w rejonie linii pomiarowej-okres 2-3 


\subsection{Results of parameter identification}

Initial testing included the calculation of all parameters, including operation rim (edge effect offset). The obtained value of the operation rim was negligible. This parameter was omitted in further calculations.

The influence of drainage on the shape of the subsidence trough profile was not taken into account.
The residual standard deviation (Drzęźla 1989) as measure of uncertainty of parameter values was assumed.

The calculation results for analysed cases are presented in Tables 2, 3 and 4. Figures 7 and 8 illustrate the subsidence obtained from the geodetic survey as well as the value of subsidence calculated theoretically for Knothe's model.

Tab. 2. Results of calculation for periods: $0-1,0-2$ and $0-3$ (measured subsidence "s", calculated subsidence "st")

Tab. 2. Wyniki obliczeń dla okresów 0-1, 0-2 i 0-3 (osiadanie pomierzone ,s”, osiadanie obliczone „st”)

\begin{tabular}{|c|c|c|c|c|c|c|c|c|c|}
\hline \multirow[b]{2}{*}{ Point } & \multicolumn{3}{|c|}{ Period 0-1 } & \multicolumn{3}{|c|}{ Period 0-2 } & \multicolumn{3}{|c|}{ Period 0-3 } \\
\hline & $\mathbf{s},[\mathrm{m}]$ & st, [m] & $\begin{array}{c}\mathbf{v}=\mathbf{s}-\mathbf{s t}, \\
{[\mathbf{m}]}\end{array}$ & $\mathbf{s},[\mathrm{m}]$ & st, [m] & $\begin{array}{c}\mathbf{v}=\mathbf{s} \text {-st, } \\
{[\mathrm{m}]}\end{array}$ & $\mathbf{s},[\mathbf{m}]$ & st, [m] & $\begin{array}{c}\mathbf{v}=\mathbf{s} \text {-st } \\
{[\mathrm{m}]}\end{array}$ \\
\hline 12 & -0.184 & -0.251 & 0.067 & -0.501 & -0.508 & 0.007 & -2.137 & -2.300 & 0.163 \\
\hline 13 & -0.354 & -0.412 & 0.058 & -0.981 & -1.051 & 0.070 & -2.933 & -2.985 & 0.052 \\
\hline 14 & -0.666 & -0.585 & -0.081 & -1.672 & -1.680 & 0.008 & -4.017 & -4.180 & 0.163 \\
\hline 15 & -0.725 & -0.743 & 0.018 & -2.336 & -2.371 & 0.035 & - & - & - \\
\hline 16 & -0.713 & -0.709 & -0.004 & -2.407 & -2.410 & 0.003 & -5.508 & -5.376 & -0.132 \\
\hline 17 & -0.570 & -0.563 & -0.007 & -2.155 & -2.114 & -0.041 & -5.278 & -5.231 & -0.047 \\
\hline 18 & -0.367 & -0.386 & 0.019 & -1.686 & -1.628 & -0.058 & -4.641 & -4.461 & -0.180 \\
\hline 19 & -0.193 & -0.206 & 0.013 & -0.996 & -1.045 & 0.049 & -2.645 & -2.797 & 0.152 \\
\hline 20 & -0.118 & -0.084 & -0.034 & -0.456 & -0.447 & -0.009 & -0.834 & -0.532 & -0.302 \\
\hline 21 & -0.100 & -0.065 & -0.035 & -0.334 & -0.312 & -0.022 & -0.539 & -0.235 & -0.304 \\
\hline 22 & -0.091 & -0.076 & -0.015 & -0.284 & -0.262 & -0.022 & -0.437 & -0.210 & -0.227 \\
\hline 23 & -0.080 & -0.077 & -0.003 & -0.246 & -0.184 & -0.062 & -0.369 & -0.084 & -0.285 \\
\hline 24 & -0.081 & -0.059 & -0.022 & -0.251 & -0.087 & -0.164 & -0.359 & -0.011 & -0.348 \\
\hline 25 & -0.065 & -0.031 & -0.034 & -0.192 & -0.023 & -0.169 & -0.282 & 0.000 & -0.282 \\
\hline 26 & -0.056 & -0.019 & -0.037 & -0.178 & -0.009 & -0.169 & -0.253 & 0.000 & -0.253 \\
\hline 27 & -0.049 & -0.012 & -0.037 & -0.157 & -0.004 & -0.153 & -0.218 & 0.000 & -0.218 \\
\hline
\end{tabular}

Tab. 3. Results of calculation for periods: 1-2 i 2-3 (measured subsidence "s", calculated subsidence "st")

Tab. 3. Wyniki obliczeń dla okresów: 1-2 i 2-3 (osiadanie pomierzone „s”, osiadanie obliczone „st”)

\begin{tabular}{|c|c|c|c|c|c|c|}
\hline \multirow{2}{*}{ Point } & \multicolumn{3}{|c|}{ Period 1-2 } & \multicolumn{3}{c|}{ Period 2-3 } \\
\cline { 2 - 7 } & $\mathbf{s ,}[\mathbf{m}]$ & $\mathbf{s t},[\mathrm{m}]$ & $\mathbf{v}=\mathbf{s}-\mathbf{s t},[\mathbf{m}]$ & $\mathbf{s ,}[\mathbf{m}]$ & $\mathbf{s t},[\mathbf{m}]$ & v=s-st, [m] \\
\hline $\mathbf{1 2}$ & -0.317 & -0.285 & -0.032 & -1.636 & -1.937 & 0.301 \\
\hline $\mathbf{1 3}$ & -0.627 & -0.629 & 0.002 & -1.952 & -2.352 & 0.400 \\
\hline $\mathbf{1 4}$ & -1.006 & -1.024 & 0.018 & -2.345 & -2.686 & 0.341 \\
\hline $\mathbf{1 5}$ & -1.611 & -1.544 & -0.067 & - & - & - \\
\hline $\mathbf{1 6}$ & -1.694 & -1.641 & -0.053 & -3.101 & -2.632 & -0.469 \\
\hline
\end{tabular}


Table 3 cont.

\begin{tabular}{|c|c|c|c|c|c|c|}
\hline \multirow{2}{*}{ Point } & \multicolumn{3}{|c|}{ Period 1-2 } & \multicolumn{3}{c|}{ Period 2-3 } \\
\cline { 2 - 7 } & $\mathbf{s , ~}[\mathbf{m}]$ & $\mathbf{s t},[\mathbf{m}]$ & $\mathbf{v}=\mathbf{s}-\mathbf{s t},[\mathbf{m}]$ & $\mathbf{s},[\mathbf{m}]$ & $\mathbf{s t ,}[\mathbf{m}]$ & $\mathbf{v}=\mathbf{s}-\mathbf{s t},[\mathbf{m}]$ \\
\hline $\mathbf{1 7}$ & -1.585 & -1.545 & -0.040 & -3.123 & -2.957 & -0.166 \\
\hline $\mathbf{1 8}$ & -1.319 & -1.320 & 0.001 & -2.955 & -2.854 & -0.101 \\
\hline $\mathbf{1 9}$ & -0.803 & -0.974 & 0.171 & -1.649 & -1.669 & 0.020 \\
\hline $\mathbf{2 0}$ & -0.338 & -0.453 & 0.115 & -0.378 & -0.178 & -0.200 \\
\hline $\mathbf{2 1}$ & -0.234 & -0.310 & 0.076 & -0.205 & -0.003 & -0.202 \\
\hline $\mathbf{2 2}$ & -0.193 & -0.229 & 0.036 & -0.153 & 0.000 & -0.153 \\
\hline $\mathbf{2 3}$ & -0.166 & -0.133 & -0.033 & -0.123 & 0.000 & -0.123 \\
\hline $\mathbf{2 4}$ & -0.170 & -0.046 & -0.124 & -0.108 & 0.000 & -0.108 \\
\hline $\mathbf{2 5}$ & -0.127 & -0.007 & -0.120 & -0.090 & 0.000 & -0.090 \\
\hline $\mathbf{2 6}$ & -0.122 & -0.001 & -0.121 & -0.075 & 0.000 & -0.075 \\
\hline $\mathbf{2 7}$ & -0.108 & 0.000 & -0.108 & -0.061 & 0.000 & -0.061 \\
\hline
\end{tabular}

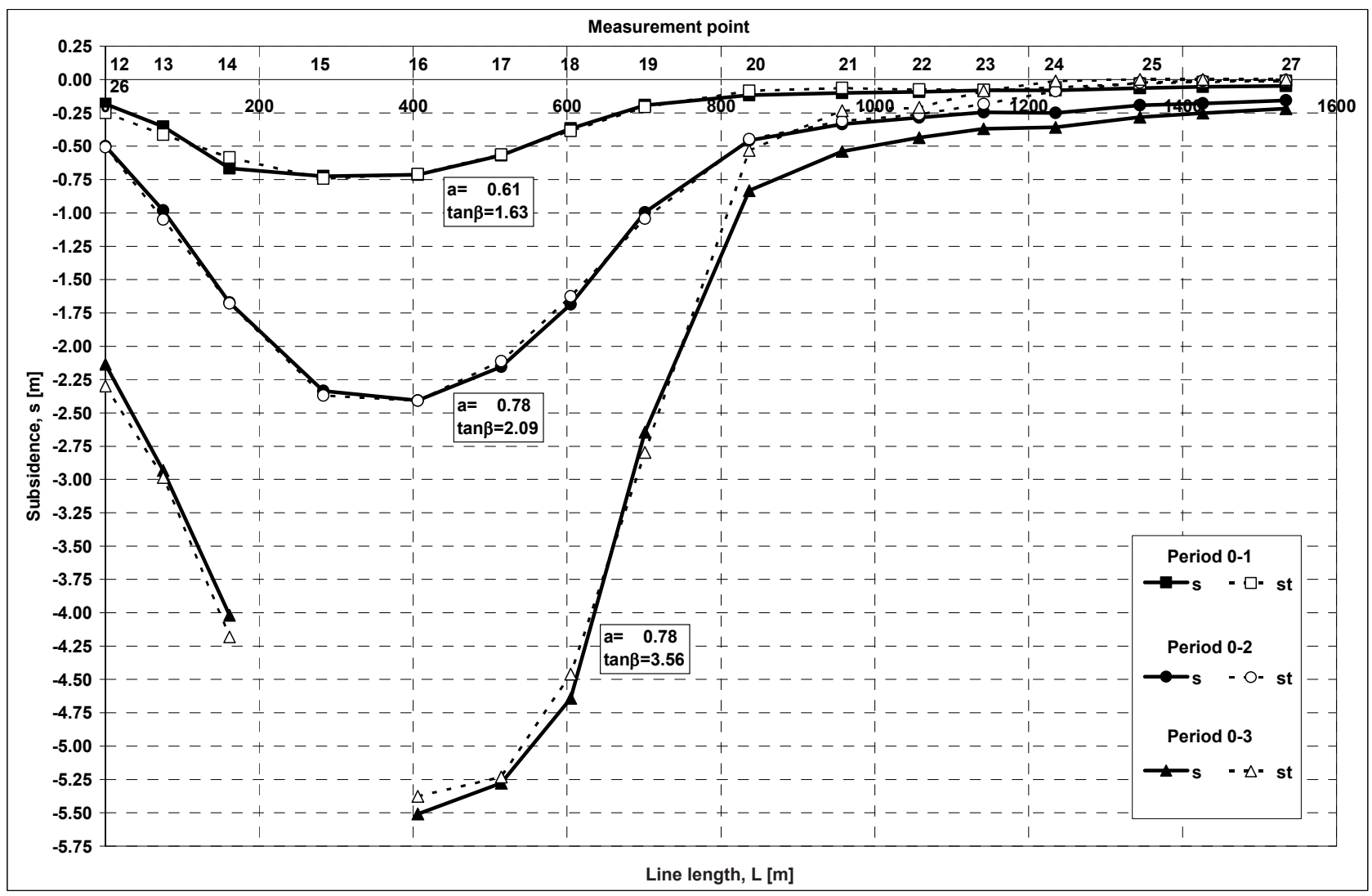

Fig. 7. Comparison of measured subsidence "s" with subsidence predictions "st" obtained from Knothe's model using calculated values of parameters (period: $0-1,0-2$ and $0-3$ )

Rys. 7. Niecki osiadania otrzymane na podstawie pomiarów geodezyjnych „s” i obliczone przy wyznaczonych wartościach parametrów „st” (okres: 0-1, 0-2 i 0-3) 
Tab. 4. Values of Knothe's model parameters

Tab. 4. Wartości parametrów teorii S. Knothego

\begin{tabular}{|l|c|c|c|c|c|}
\hline & Period 0-1 & Period 0-2 & Period 0-3 & Period 1-2 & Period 2-3 \\
\hline Coefficient of roof control $\boldsymbol{a}$ & 0.61 & 0.78 & 0.78 & 0.89 & 0.83 \\
\hline tan $\boldsymbol{\beta}$ parameter & 1.63 & 2.09 & 3.56 & 2.14 & 4.72 \\
\hline Residual standard deviation $\boldsymbol{\delta}$ [mm] & 37 & 77 & 181 & 84 & 217 \\
\hline Correlation coefficient $\boldsymbol{r}$ & 0.989 & 0.995 & 0.996 & 0.990 & 0.984 \\
\hline
\end{tabular}

The analysis of the obtained values of the parameters shows their increase resulting from the exploitation of subsequent coal seams. The value of the subsidence coefficient $a$ (Fig. 9) in the analyzed cases after selecting the third coal seam was constant, while the value of the parameter describing the dispersion of the effects $\tan \beta$ increased (Fig. 10) to a maximum value far greater than those known in the literature (Knothe 1984). The high value of the parameter $\tan \beta$ indicates an increase in the level of rock mass fracture as a result of the extraction in the subsequent coal seams, which is demonstrated by period $2-3$.

Coefficient of roof control $a$ of 0.89 obtained for calculations in period 2-3 may be a result of the com-

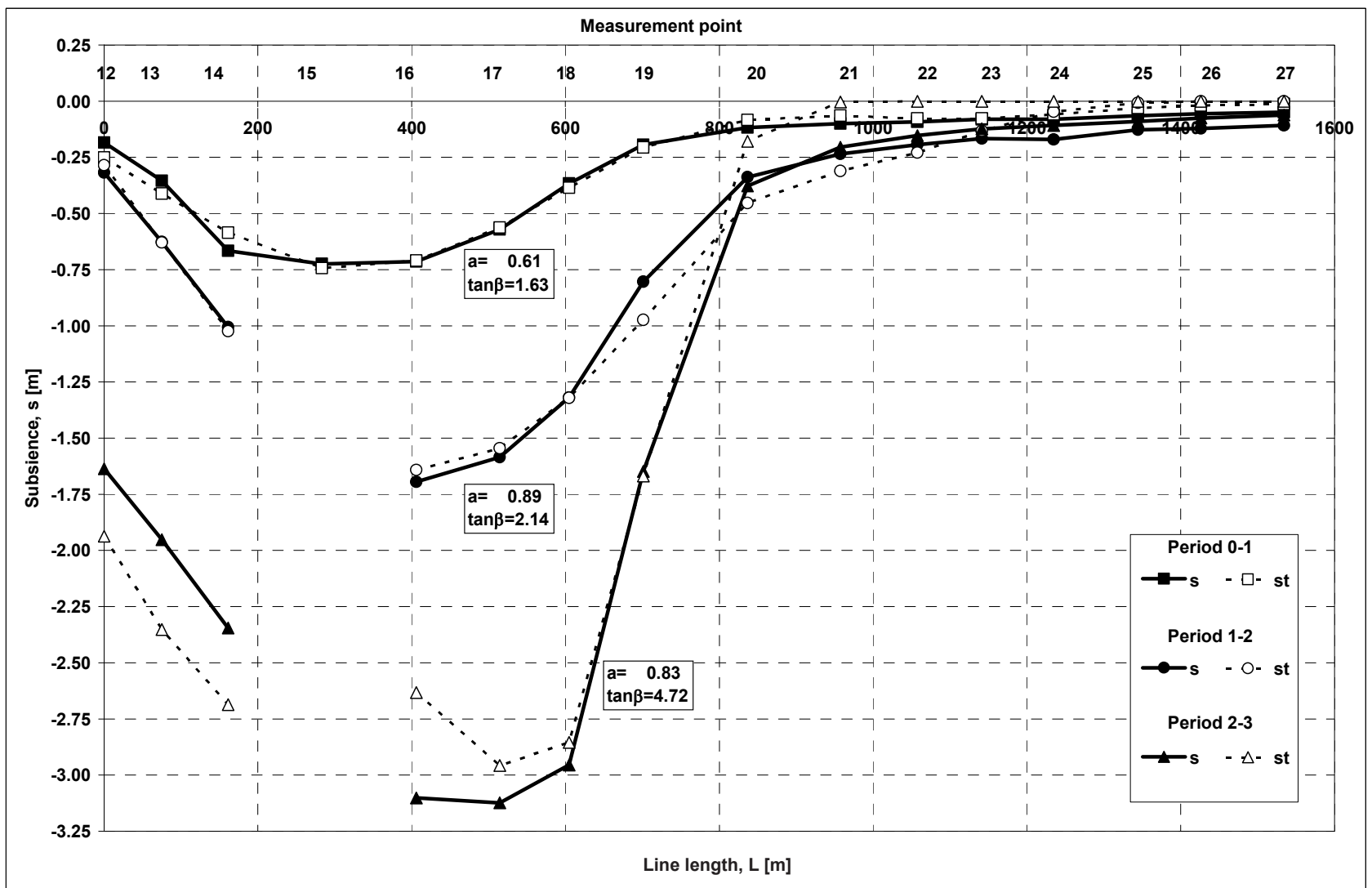

Fig. 8. Comparison of measured subsidence "s" with subsidence predictions "st" obtained from Knothe's model using calculated values of parameters (period: $0-1,1-2$ and $2-3$ )

Rys. 8. Niecki osiadania otrzymane na podstawie pomiarów geodezyjnych „s” i obliczone przy wyznaczonych wartościach parametrów „st” (okres: 0-1, 1-2 i 2-3) 


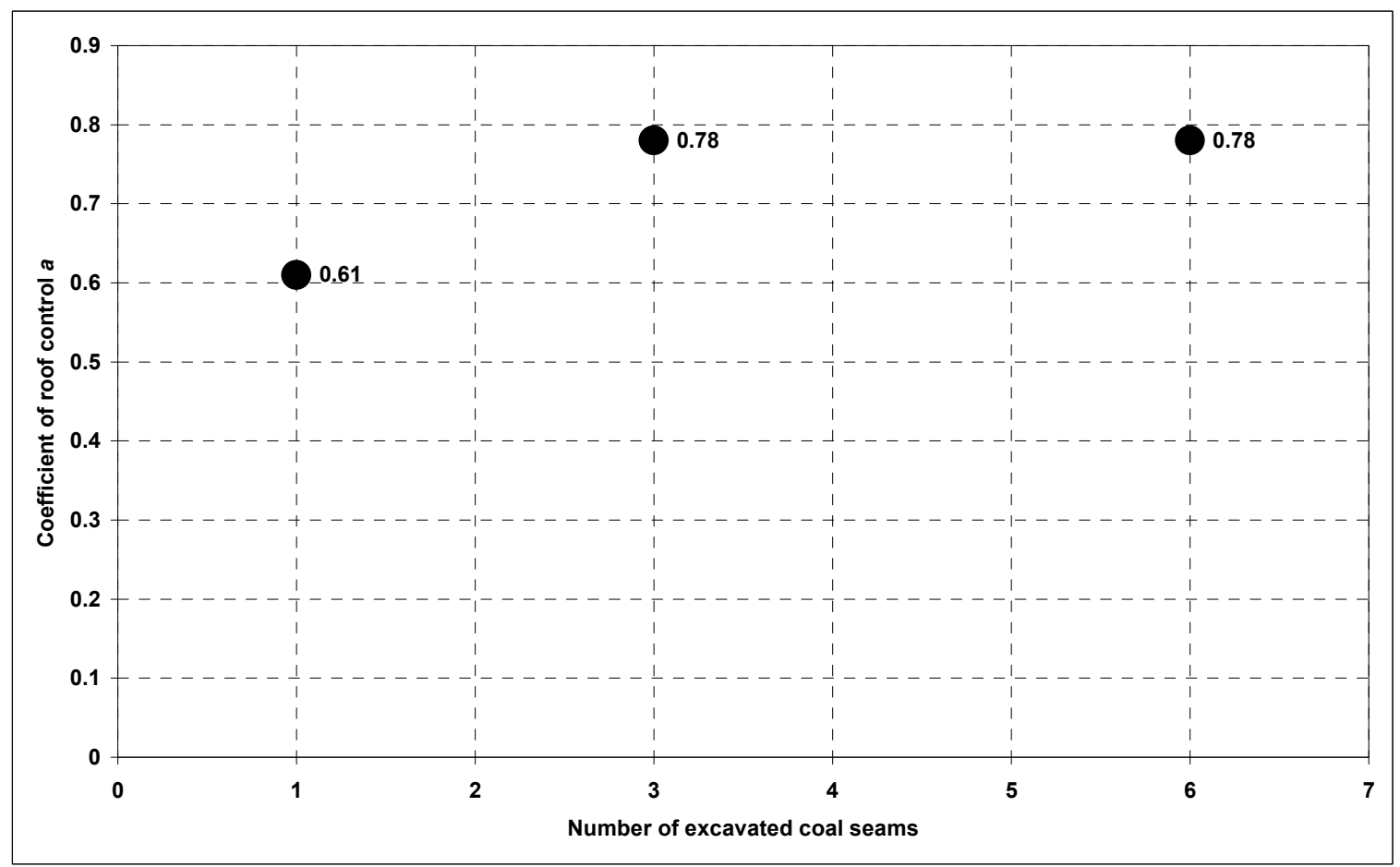

Fig. 9. Relationship between values of coefficient of roof control "a" and number of excavated coal seams Rys. 9. Wykres przedstawiający zależność wartości współczynnika osiadania „a” od liczby wybranych pokładów

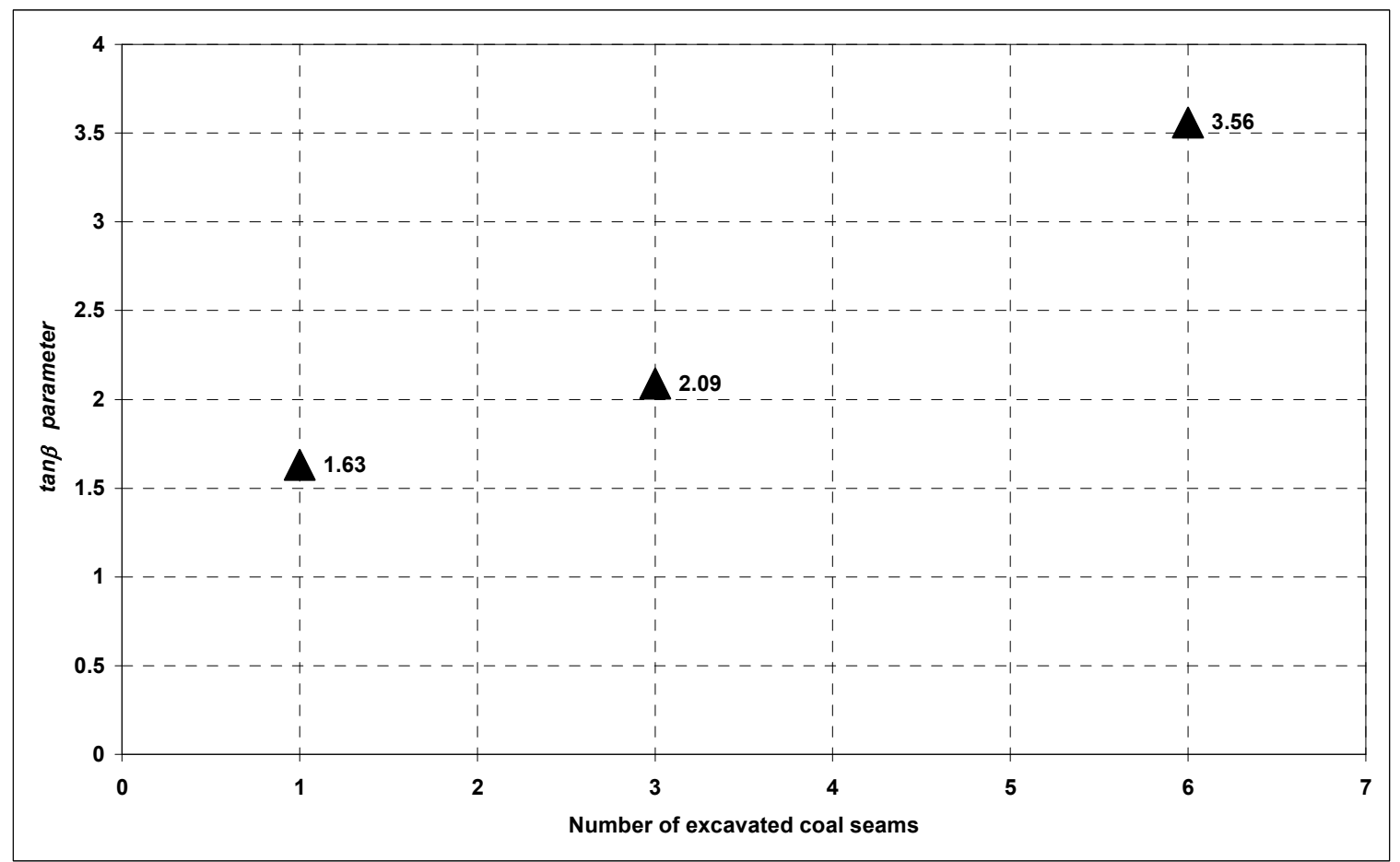

Fig. 10. Relationship between values of $\tan \beta$ parameter and number of excavated coal seams Rys. 10. Wykres przedstawiający zależność wartości parametru tg $\beta$ od liczby wybranych pokładów 
pression of excavations in previously depleted coal seams in the process of rock deformation (Popiołek 2009), as well as it may be caused by closing of the interstitial spaces, also called "Weber's voids".

\section{SUMMARY}

Long-term forecasts of the impact of mining on the surface require accurate identification of the changes in the theoretical patterns that describe the final state of the rock deformation.

The paper presents the results of the identification of parameters of Knothe's model for multi-seam and long-term mining operations. The research shows important changes in the values of the parameters describing asymptotic state of deformation. These are the result of the impact of the rock mass on the subsequent coal seams. At the same time, it can be seen that the final value of $\tan \beta$ parameter equals 3.56 in the last analyzed period is outside the range which was proposed by S.Knothe to be used in the conditions of Upper Silesian Coal Basin (from 1.5 to 2.5) (Knothe 1984). S. Knothe additionally mentions that, in rare cases, $\tan \beta$ may be greater than 3.0.

At the same time, the calculations show that taking into account changes in the value of parameters is necessary when forecasting deformation of terrain in subsequent stages of exploitation. A mine development plan document contains the final state of terrain deformation, calculated for the $\tan \beta$ parameter within the range suggested by $\mathrm{S}$. Knothe. On the basis of the research conducted in this study, this may result in a significant reduction in the quality of forecasts for the target state of excavation.

Studies have indicated that similar analyzes are needed in other regions of the Upper Silesian Coal Ba$\sin$. This will create the ability to produce more accurate long-term forecasts of the impact of mining operations on the surface and the rock mass.

\section{REFERENCES}

Białek J., Mielimąka R. (2001): Próba weryfikacji parametrów teorii prognozowania wpływów eksploatacji na teren górniczy. Zeszyty Naukowe Pol. Śl. s. Górnictwo z.250/01, s. 69-79.

Białek J., Mielimąka R. (2006): Metodyka wyznaczania wartości parametrów teorii prognozowania na przykładzie wielopokładowej eksploatacji w Polu Marklowice. VI konferencja naukowo-techniczna „Ochrona środowiska na terenach górniczych”. Szczyrk, 31.05-2.06.2006.

Chudek M., Strzałkowski P., Flisowski A. (2007): Weryfikacja metody prognozowania deformacji górotworu wykorzystującej funkcję wpływów całkowalna przez kwadraturę. Zeszyty Naukowe; Politechnika Śląska nr 1751 Górnictwo; z. 276.

Doležalová H., Kajzar V., Souček K., Staš L. (2010): Evaluation of vertical and horizontal movements in the subsidence depression near Karviná. Acta Geodyn. Geomater., Vol. 7, No. 3 (159), pp. 355-361.

Drzęźla B. (1989): Opis programów prognozowania deformacji górotworu pod wplywem eksploatacji górniczej. Aktualny stan oprogramowania, Zeszyty Naukowe Politechniki Śląskiej, s. Górnictwo, z, 165, Gliwice.

Ghabraie G., Ren G., Smith J. V. (2017): Characterizing the multi-seam subsidence due to varying mining configuration, insights from physical modelling. Journal of Rock Mechanics \& Mining Sciences 93, pp. 269-279.

Ghabraie B., Ren G., Barbato J., Smith J.V. (2017): A predictive methodology for multi-seam mining induced subsidence. Journal of Rock Mechanics \& Mining Sciences 93, pp. 280-294.

Gruszczyński W., Niedojadło Z., Mrocheń D. (2018): Influence of model parameter uncertainties on forecasted subsidence. Acta Geodyn. Geomater., Vol. 15, No. 3 (191), pp. 211-228 .

Hejmanowski R., Malinowska A. (2009): Evaluation of reliability of subsidence prediction based on spatial statistical analysis. International Journal of Rock Mechanics \& Mining Sciences 46, pp. 432-438.

Hejmanowski R., Malinowska A. (2016): Significance of the uncertainty level for the modeling of ground deformation ranges. International Journal of Rock Mechanics \& Mining Sciences 83, pp. 140-148.

Hescock J., Newman C., Agioutantis Z. (2018): Development of a new algorithm for implementing the edge effect offset for subsidence calculations. Journal of Rock Mechanics \& Mining Sciences 28, pp. 61-66.

Knothe S.: 1953, Równanie profilu ostatecznie wyksztatconej niecki osiadania, Archiwum Górnictwa i Hutnictwa. Kwartalnik Tom 1, zeszyt 1, Warszawa, pp. 22-38.

Knothe S. (1984): Prognozowanie wptywów eksploatacji górniczej, Wydawnictwo „Śląsk”, Katowice.

Kowalski A. (1984): Określenie zmienności parametru promienia zasięgu wplywów głównych $w$ górotworze $r(z)$ teorii Budryka-Knothego na podstawie badań geodezyjnych przemieszczen pionowych górotworu, Praca doktorska (niepublikowana), Katowice.

Kowalski A. (2015): Deformacje powierzchni w Górnośląskim Zagłębiu Węlowym. Główny Instytut Górnictwa, Katowice.

Kruczkowski M. (2019): Identification of theoretical parameters used to forecast impact of underground mining on one coal seam performed on the basis of a geodetic survey. IOP Conference Series; Earth and Environmental Science; vol. 261, pp. 1755-1315. 
Mielimąka R. (2019): Weryfikacja parametrów teorii prognozowania dla rejonu intensywnej, wielopoktadowej eksploatacji górniczej, Syst. Wspomag. Inż. Prod. Systemy Wspomagania Inżynierii Produkcji 2019 vol. 8 iss. 1, s. 429-438.

Popiołek E. (2009): Ochrona terenów górniczych, Wydawnictwa AGH, Kraków.

Rozporządzenie Ministra Środowiska z dnia 24 kwietnia 2012 r. w sprawie szczegółowych wymagań dotyczących projektów zagospodarowania złóż, Dziennik Ustaw RP poz. 511, Warszawa dnia 14 maja $2012 \mathrm{r}$.

Singh K. B., Singh T. N. (1998): Ground movements over longwall workings in the Kamptee coalfield, India Engineering Geology 50, pp. 125-139.

Singh R. P., Yadav R. N. (1995): Prediction of subsidence due to coal mining in Raniganj coalfield, West Bengal, India Engineering Geology 39 pp. 103-111.

Strzałkowski P. (1989): Wpływ warunków geologiczno-górniczych na parametry asymetrycznego rozkładu deformacji powierzchni terenu, Praca doktorska (niepublikowana), Gliwice.
Ścigała R. (2006): Identyfikacja wartości parametrów teorii prognozowania wplywów w warunkach intensywnej eksploatacji górniczej, Kwartalnik „Górnictwo i Geologia” Tom 1. Zeszyt 2. Gliwice, pp. 77-85

Tajduś K. (2007): Numeryczne określanie metoda elementów skończonych wpływu eksploatacji na powierzchnię. Przegląd Górniczy nr 5, pp. 36-42.

Tyrała A. (1993): Wplyw eksploatacji wielokrotnej na wartości parametrów $i$ wspótczynników stosowanych przy prognozowaniu deformacji powierzchni, Materiały Konferencji naukowo-technicznej ,II Dni Miernictwa Górniczego i Ochrony Terenów Górniczych", Ustroń-Jaszowiec 19-21 maja 1993 r., pp. 295-301.

Wesołowski M. (2013): Zastosowanie liniowego ośrodka transwersalnie izotropowego do modelowania deformacji terenu górniczego. Wydawnictwo Politechniki Śląskiej, Gliwice.

Zych J. (2000): The subsidence analysis in time on the grounds of geodetic measurements for ,Budryk” coal mine, Materiały $11^{\text {th }}$ International Congress of the International Society for Mine Surveying. Vol. 2. Kraków, wrzesień 2000, pp. 49-59. 